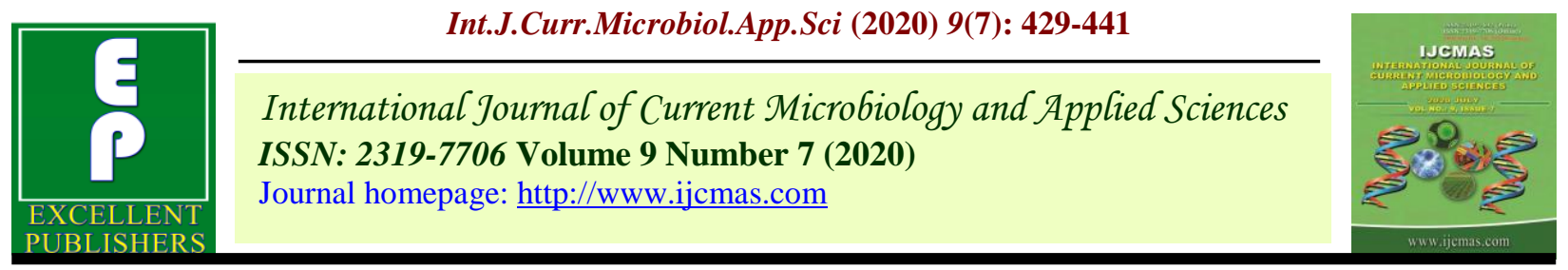

Original Research Article

https://doi.org/10.20546/ijcmas.2020.907.048

\title{
Evaluation of Foliar Application of Different Types of Nanofertilizers on Growth, Yield and Quality Parameters and Nutrient Concentration of Cotton under Irrigated Condition
}

\author{
D. Kanjana* \\ Central Institute for Cotton Research, Regional Station, \\ Coimbatore - 641 003, Tamil Nadu, India \\ *Corresponding author
}

\begin{tabular}{|l|}
\hline Ke y w o r d s \\
$\begin{array}{l}\text { Nanofertilizers, } \\
\text { seed cotton yield, } \\
\text { foliar spray, nutrient } \\
\text { concentration }\end{array}$ \\
\hline Article Info \\
\hline $\begin{array}{l}\text { Accepted: } \\
\text { 05 June } 2020 \\
\text { Available Online: } \\
\text { 10 July } 2020\end{array}$ \\
\hline
\end{tabular}

\section{A B S T R A C T}

Two years (2014-15 and 2015-16) of field experiments were conducted under winter irrigated conditions on Periyanaicken palayam soil series (Vertic Ustropept) at Central Institute for Cotton Research, Regional Station, Coimbatore to study the effect of different types of commercially available nanofertilizers on cotton growth and yield. Combined form of macro and micronutrient nanofertilizers (NF 1, NF 2, NF 3 and NF 4) compared with recommended dose of combined form of normal micronutrient fertilizers which were sprayed on cotton (var: Suraj) at 30 and 90 DAS. The results clearly revealed that foliar application of recommended dose of NF 3 and NF 4 nanofertilizers significantly increased the seed cotton yield by 16.0 and $14.4 \%$ respectively over normal recommended dose of micronutrients which was followed by NF $2(9.5 \%)$ and NF $1(9.2 \%)$ nanofertilizers. However, fibre quality parameters were not significantly influenced by foliar application of commercially available nanofertilizers. All the macro nutrients ( N, P and $\mathrm{K}$ ) concentration were significantly affected in one or both years due to foliar spraying of commercially available nanofertilizers, but among the micronutrients, copper is the only micronutrient to show their significance. Overall, application of commercially available nanofertilizers considerably increased the number of opened bolls, boll weight and seed cotton yield as compared to normal recommended dose of micronutrients and control.

\section{Introduction}

In India, Cotton (Gossypium hirsutum: Malvaceae), popularly known as 'White Gold' is one of the most important commercial crops and accounts for around $25 \%$ of the total global fibre production. About 60 million people are involved in cotton production, textile industry and trade. During 2018-19, India stands first position in cotton acreage (12.6 million ha) and production (33.7 million bales) but the productivity is very low $(454.4 \mathrm{~kg} / \mathrm{ha})$ as compared to USA (955 kg/ha) and China (1764 kg/ha) (Cotton Advisory Board, 2019).

Approximately $62 \%$ of India's Cotton is produced on rain-fed areas and 38\% on irrigated lands. Among the various yield limiting factors, poor soil fertility and 
improper nutrient management practice are considered as significant factors for low productivity. Hence, to improve the cotton productivity, advanced and novel nutrient management strategies are inevitable.

Nowadays, nanotechnology is an emerging science that has the potential to revolutionize the agriculture with new concepts, ideas and tools for maximizing the productivity and reduce the poverty (Norman and Hongda, 2013). Nanotechnology based products are occupying every nook and corner of the world due to its special properties like smaller size (1-100 nm at least in any one of the dimension), large surface to volume ratio, higher chemical reactivity, enhanced solubility and unique magnetic and optical properties. In recent times, some of the nano agricultural products like nanofertilizers and nanopesticides are commercially available in the market and some of them are in pipeline of patenting.

Particularly, nanofertilizers got much attention among the researchers and fertilizer industries due to their controlled and targeted delivery mechanism to increase the fertilizer use efficiency and nutrient uptake ratio without any losses of nutrients and thus able to improve the crop productivity by enhancing the seed germination, seedling growth, photosynthetic activity, energy metabolism, protein synthesis, enzymesrelated functions and others (Solanki et al., 2015)

As compared to conventional fertilizers, nanofertilizers are considered as efficient alternate fertilizers to improve the dissolution rate and to enhance the nutrient use efficiency due to their smaller size (Kanjana, 2017), so that the particle can easily penetrate into the root and leaf cuticular cells through soil and foliar applications, respectively (Perez-deLuque, 2017). Even though nanofertilizers are much interested by the farmers due to their much potentiality as compared to conventional fertilizers, but the people are unaware about the commercial products and their effectiveness on plants health.

Therefore, an attempt was made to find out the efficiency of foliar application of conventional micronutrient fertilizer and commercially available micronutrient nanofertilizers on cotton growth and yield.

\section{Materials and Methods}

Field experiments were conducted at ICAR Central Institute for Cotton Research, Regional Station, Coimbatore during 2014-15 and 2015-16 with the test crop cotton (var:Suraj) to evaluate the effects of foliar application of commercially available nanofertilizers on cotton plant growth and yield. The experimental design was laid out in Randomized Block Design (RBD) with three (2014-15) and four (2015-16) replications.

The experimental soil was clay loam in texture, alkaline in reaction (8.50), non saline $\left(0.25 \mathrm{dS} \mathrm{m}^{-1}\right)$ with moderate CEC $(21.2 \mathrm{cmol}$ $\left(\mathrm{p}^{+}\right) \mathrm{kg}^{-1}$ and organic carbon $(0.58 \%)$ content. The available nutrient status of the soil was low for available $\mathrm{N}\left(170 \mathrm{~kg} \mathrm{ha}^{-1}\right)$, medium for available $\mathrm{P}\left(11.5 \mathrm{~kg} \mathrm{ha}{ }^{-1}\right)$ and high for available $\mathrm{K}\left(888 \mathrm{~kg} \mathrm{ha}^{-1}\right)$. The DTPA extractable micronutrient status of soil was having $0.83,2.85,1.60$ and $13.4 \mathrm{ppm}$ of zinc, iron, copper and manganese respectively.

Seeds were sown manually in rows $75 \mathrm{~cm}$ apart and plant to plant distance of $45 \mathrm{~cm}$. Plot size was $4.5 \mathrm{~m}$ length and $3.75 \mathrm{~m}$ breadth $\left(16.88 \mathrm{~m}^{2}\right)$. For all the treatments, recommended dose of fertilizer $(60: 30: 30 \mathrm{~kg}$ NPK ha ${ }^{-1}$ ) was applied uniformly, in which P \& $\mathrm{K}$ was applied as basal and $\mathrm{N}$ was applied at sowing (50\%), $45(25 \%)$ and $90(25 \%)$ DAS. 
All the other agronomic practices were followed as per the standard procedure.

The commercially available nanofertilizers like NF 1 (nanofertilizer) contains higher amount of secondary nutrient like $\mathrm{Ca}$ with smaller amount of $\mathrm{Mg}, \mathrm{Si}$ and trace amounts of $\mathrm{Fe}, \mathrm{Zn}, \mathrm{Cu}, \mathrm{Mo}$ and $\mathrm{Co}$. This nanofertilizer was produced by using a patented technology "Tribo Mechanical Activation process" (TMA technology). Next, the nutrient composition of NF 2 was combination of macro (N, P and K), secondary ( $\mathrm{Ca}, \mathrm{Mg}, \mathrm{S}$ ), micro (Fe, $\mathrm{Mn}, \mathrm{Zn}$, $\mathrm{Cu}, \mathrm{Mo}$ and $\mathrm{B})$ and other nutrients $(\mathrm{Co}, \mathrm{Cr}, \mathrm{I}$, $\mathrm{Na}, \mathrm{Cl}, \mathrm{Si}, \mathrm{Se}, \mathrm{Ag}, \mathrm{Au}$ and $\mathrm{C}$ ) with 23 amino acids and vitamins (A, B, C, D, E, K). Likewise, NF 3 comprised of macro $\left(\mathrm{P}_{2} \mathrm{O}_{5}\right.$ and $\left.\mathrm{K}_{2} \mathrm{O}\right)$, secondary $(\mathrm{Ca}, \mathrm{Mg}, \mathrm{S})$, micro $(\mathrm{Fe}$, $\mathrm{Mn}, \mathrm{Zn}, \mathrm{Cu}, \mathrm{Mo}$ and $\mathrm{B}$ ) and other nutrients $\left(\mathrm{Co}\right.$ and $\mathrm{SiO}_{2}$ ). Finally, NF 4 contains only micronutrients ( $\mathrm{Fe}, \mathrm{Mn}, \mathrm{Zn}, \mathrm{Cu}, \mathrm{Mo}$ and $\mathrm{B}$ ), particularly cations in the form of chelates. The experimental treatment consists of T1 Control (water spray), T2 - Normal micronutrients ( $\mathrm{Zn}, \mathrm{Fe}, \mathrm{Cu}, \mathrm{Mn}$ and $\mathrm{B}$ ), T3 NF 1, T4 - NF 2, T5 - NF 3 and T6 - NF 4.

Recommended dose of normal micronutrients (T2) ie., combinations of $\mathrm{ZnSO}_{4}(0.5 \%)$, Boric acid (0.2\%), $\mathrm{CuSO}_{4} \quad(0.5 \%)$, $\left.\mathrm{FeSO}_{4}(0.5 \%), \mathrm{MnSO}_{4}(1.0 \%)\right), \mathrm{NF} 2(2.5 \mathrm{~g} / \mathrm{lit}$ of water), NF $3(50 \mathrm{ml} / 200$ lit of water), NF 4 $(500 \mathrm{ml} / 250$ lit of water) and NF 5 (0.75 g/lit of water) were applied as foliar spray during 30 and 90 days after sowing ie., at both vegetative and flowering stage. Plant growth attributes viz., plant height and number of leaves, leaf area index and total chlorophyll content were recorded at 15 days after spray and maturity stage. Likewise, seed cotton yield and dry matter production were collected at harvest stage. The quality parameters viz., $2.5 \%$ span length, uniformity ratio, micronaire, fibre strength and 100 seed weight were analyzed by using high volume instruments (HVI, Statex- Fibrotex model).
Macro nutrients like N, P and $\mathrm{K}$ content for both years and micronutrients viz., $\mathrm{Zn}, \mathrm{Fe}, \mathrm{Cu}$ and $\mathrm{Mn}$ for 2014-15 were analyzed in whole plants of cotton at harvest stage of the crop. Data were statistically analyzed using standard analysis of variance.

\section{Results and Discussion}

\section{Growth and physiological parameters}

Plant growth parameter like plant height was increased by foliar application of commercially available nanofertilizers and normal source of micronutrients in cotton (Fig. 1). NF 4 and NF 1 nanofertilizers increased the plant height at square formation (45 DAS) and harvest stage of the crop than normal source of micronutrients and control. Similarly, physiological attribute of leaf area index (LAI) was also higher in both nanofertilizers like NF 4 (1.90) and NF 1 (1.85) applied plants than other nanofertilizers viz., NF 2 (1.59) and NF 3 (1.58) (Fig 2). The performance of other two nanofertilizers like NF 3 and NF 2 were more or less equal with normal micronutrients on plant height and LAI. Since NF 1 nanofertilizers containing higher amount of calcium nutrient $(44.08 \%)$, plant biomass attributing characters like plant height $(2.7 \%)$ and LAI $(18.6 \%)$ were enhanced than normal source of micronutrients and this might be due to cell elongation process rendered by calcium nutrient. Hirschi (2004) opined that calcium is highly required for strengthen the cell wall and also involved in cell elongation and cell division process. Moreover, silicon content $(10.98 \%)$ was also higher in this nanofertilizer which influences formation of thicker cell walls for bigger stems and facilitates faster growth rate. The beneficial element of silicon has positive effects on both monocot and dicot plants especially rice, where accumulation of silica provides stem strengthness by increasing the culm wall 
thickness and vascular bundles size. Besides, silica promotes cell extension in plants, which results in better and rapid plant growth (Sahebi et al., 2015). Flores et al., (2018) reported that leaf area of sorghum was increased by upto $23 \%$ with the use of foliar spray of $3.36 \mathrm{~g} / \mathrm{L}$ of $\mathrm{Si}$. As like, chelated micronutrients in the form of nano (NF 4) remarkably improved the plant growth characteristics like plant height $(2.8 \%)$ and LAI $(21.8 \%)$ over normal micronutrients. Similar findings were reported by Padma et al., (1989), Dordas, (2009), Tahir et al., (2009) and Ajamal et al., (2018).

Regarding the total chlorophyll content of cotton leaves, the highest $(0.807 \mathrm{mg} / \mathrm{g})$ was recorded by foliar application of NF 3 nanofertilizer, while the lowest (0.759) was noted in NF 1 nanofertilizer treatment (Fig 2). The higher photosynthetic activity was enhanced by 1-100 nm particle size of NF 3 foliar spray which contains all the macro $(\mathrm{P}$, $\mathrm{K})$, secondary ( $\mathrm{Ca}, \mathrm{Mg} \& \mathrm{~S})$, micro $(\mathrm{Zn}, \mathrm{Fe}$, $\mathrm{Mn}, \mathrm{Cu}, \mathrm{Mo}, \mathrm{B})$ and beneficial (Co \& $\mathrm{Si}$ ) nutrients except the vital component of chlorophyll production ie., nitrogen. In contrary, the lowest total chlorophyll content was observed in NF 1 nanofertilizer which may be due to the absence of chlorophyll forming elements except the meager amount of magnesium nutrient $(2.02 \%)$.

\section{Yield parameters}

The results of two year field experimental study revealed that significant effect was aroused on seed cotton yield and total dry weight of plant due to foliar application of commercially available nanofertilizers but number of symbodial branches per plant and number of opened bolls per plant were not significantly affected (Table 1). The average number of symbodial branches and number of opened bolls per plant was higher in foliar application of NF 3 (22.7 and 16.8), NF 4
(22.1 and 16.9), NF 2 (22.3 and 16.5) and NF 1 (21.8 and 14.7) nanofertilizers than normal micronutrients containing foliar spray (22.0 and 15.6) and control (21.6 and 14.7). The significant increase of seed cotton yield was obtained in both years (2014-15 and 2015-16) due to foliar application of NF 3 (1403 and $1336 \mathrm{~kg} \mathrm{ha}^{-1}$ ) and NF 4 (1407 and $1293 \mathrm{~kg} \mathrm{ha}^{-}$ $\left.{ }^{1}\right)$ nanofertilizers as compared to other two nanofertilizers like NF 2 (1383 and $1202 \mathrm{~kg}$ $\mathrm{ha}^{-1}$ ) and NF 1 (1327 and $1250 \mathrm{~kg} \mathrm{ha}^{-1}$ ) but it was superior than normal micronutrients spray (1277 and $1082 \mathrm{~kg} \mathrm{ha}^{-1}$ ) control (1257 and $\left.1107 \mathrm{~kg} \mathrm{ha}^{-1}\right)$.

On an average of two years of field experiment, foliar application of recommended dose of NF 3 nanofertilizer significantly increased the seed cotton yield by $16.0 \%$ over normal micronutrients. A patented nanofertilizer with base of $\mathrm{SiO}_{2}$ nanocomposite enhanced the accumulation of photosynthates by increasing the total chlorophyll content and then it was translocated into sink for significant increment of seed cotton yield.

The positive effects of foliar sprayed $\mathrm{SiO}_{2}$ nanoparticles on plant growth and yield parameters were reported in fababean (Abdul Qados and Moftah, 2015), safflower (Janmohammadi et al., 2016) and cucumber (Yassen et al., 2017) which was mainly due to their unique physical and chemical properties of nanoparticles. Moreover, the porous type $\mathrm{SiO}_{2}$ nanocomposite slowly released the mineral nutrients for better absorption and utilization of the plant.

This was in line with Wanyika et al., (2012), they explored the mesoporous silica nanoparticles for slow and sustained release of urea fertilizer and they found that 100 per cent of urea was released up to 6 days. The EDTA chelated micronutrients $(\mathrm{Zn}, \mathrm{Fe}, \mathrm{Cu}$, $\mathrm{Mn}, \mathrm{B}$ and Mo) nanofertilizer (NF 4) 
significantly enhanced the seed cotton yield by $14.4 \%$ over normal micronutrients but it was on par with NF 3 nanofertilizer. Foliar applied chelated micronutrients are easily absorbed, translocated and metabolized within the plant system (Sekhon, 2003) and hence, plant growths as well as yield parameters were increased gradually.

Shahrekizad et al., (2015) developed EDTA coated iron oxide $\left(\mathrm{Fe}_{3} \mathrm{O}_{4}\right)$ nanofertilizer and found that plant growth parameters like plant height, number of leaves, aerial organ biomass, chlorophyll content and $\mathrm{Fe}$ concentration in sunflower plants were significantly increased by both foliar and soil application. Tariq et al., (2014) revealed that foliar spray of micronutrients fulfilled the demand of the crop by higher assimilation and translocation of photosynthates from source to sink.

Nanofertilizer NF 2 contains 21 minerals, 20 amino acids and some of the vitamins, which helps to increase the seed cotton yield $(9.5 \%)$ by enhancing the photosynthetic activity, fruiting branches and fruiting bodies than normal micronutrient spray treatment. Datir et al., (2010), reported that foliar application of $2.0 \%$ of amino acid containing micronutrients ( $\mathrm{Zn}, \mathrm{Fe}, \mathrm{Cu}, \mathrm{Mn}, \mathrm{B}$ and $\mathrm{Mo}$ ) significantly enhanced the plant height, number of leaves, leaf area and yield per plant of okra. Similarly, they found the same effect in chilli with $1.5 \%$ of amino acid chelated micronutrient fertilizer. (Datir et al.2012). Jie et al., (2008) noticed the improved chlorophyll content (11-17 \%) and growth parameters $(22-73 \%)$ in rice due to foliar spraying of aminoacid chelated micronutrient $\left(\mathrm{ZnSO}_{4}\right.$ and $\left.\mathrm{FeSO}_{4}\right)$ fertilizer over the control.

NF 1 nanofertilizer remarkably increased the plant growth parameters like plant height and leaf area index of cotton, but yield parameters like number of opened bolls per plant and seed cotton yield were not increased significantly, which indicated that all the nutrients present in this nanofertilizer were highly accumulated in leaves and not transported to reproductive parts. The reason may behind that higher accumulation of calcium nutrient in leaves which helps for cell elongation to enhance the plant growth parameters (Burstrom, 2008).

Moreover, calcium can only moves up into the plant through water stream in xylem and it is associated with transpiration process (Gerbrandt et al., 2019) and does not perform phloem transport (Etienne et al., 2018). Calcium transport from the site of application to adjacent leaf through foliar is possible but further translocation or redistribution to another plant organ will not takes place due to it's immobility nature (Bukovac and Wittwer, 1957).

Regarding the sulphate form of cationic micronutrients containing normal micronutrient spray increased the number of symbodial branches per plant, number of opened bolls per plant and seed cotton yield than control in 2014-15 field experiment but these parameters were severely affected in 2015-16 due to occurrence of continuous rain during the critical stages of boll formation. Field study 2015-16 data showed that plant growth parameters like plant height, number of leaves and leaf area index were comparatively higher than 2014-15, however, all the growth and yield (number of symbodial branches per plant, seed cotton yield (Fig 3) and total dry weight of cotton plant) parameters at harvest stage were invariably reduced in the year 2015-16 due to continuous rain and severe infection of alternaria leaf spot at boll formation stage of the crop. But, major nutrient concentration $(\mathrm{N}, \mathrm{P}$ and $\mathrm{K}$ ) and $100 \mathrm{~g}$ seed weight were markedly increased in 2015-16 as compared to 2014-15. 


\section{Fibre quality parameters}

On an average of two years, most of the fibre quality parameters like $2.5 \%$ span length, uniformity ratio, micronaire value, fibre strength and 100 seed weight were not significantly influenced by foliar application of commercially available nanofertilizers (Table 2). Similarly, Temiz et al., (2009) and Rajput et al., (2016) found the non-significant effects on fibre quality parameters of cotton due to foliar application of micronutrients. However, $2.5 \%$ span length and micronaire value were significantly affected during first and second year of the experiments respectively.

The average micronaire content was increased by 4.8 per cent over control due to foliar spraying of NF 3 nanofertilizer. Eventhough $2.5 \%$ span length ie., fibre length and micronaire value $i e$., fibre fineness were little bit influenced by application of nanofertilizers and normal source of micronutrients than control, yet these fibre quality properties are mostly depends on the cultivars (Sankaranarayanan et al., 2010). Among the foliar applications, both sulphate (normal micronutrient spray) as well as chelated (NF 4) form of micronutrients appreciably increased the fibre length (4.0 and $2.6 \%)$ as well as fibre strength (6.3 and $4.1 \%$ ) of cotton respectively over control. Gobi and Vaiyapuri (2012) and Abdallah and Mohamed (2013) found the improvement in fibre length and fibre strength of cotton due to foliar spraying with micronutrients $(\mathrm{Zn}, \mathrm{Fe}, \mathrm{Cu}, \mathrm{Mn}$, $\mathrm{B}, \mathrm{Mo}$ ). Though the nonsignificant effect was noticed on 100 seed weight of cotton, foliar application of NF 4 and NF 3 increased them by 4.0 and 2.0 per cent respectively.

\section{Nutrient concentration in cotton}

The average total nitrogen content in the whole plant of cotton was in the range of 1.41 to 1.71 per cent due to foliar application of nanofertilizers. The highest total nitrogen content was registered in NF 4 nanofertilizer $(1.71 \%)$ followed by NF $3(1.57 \%)$, NF 2 $(1.43 \%)$ and NF $1(1.41 \%)$ nanofertilizers.

As compared to control (1.35\%), normal micronutrient spray $(1.43 \%)$ also improved the total nitrogen content in cotton plants.

During the year 2015-16, total nitrogen content was significant due to NF 4 and NF 3 nanofertilizers whereas the year 2014-15, non-significance was noted on total $\mathrm{N}$ content. The increased average total phosphorus content was noticed in foliar application of micronutrients either as normal or as nano form than control.

During both the years (2014-15 \& 2015-16), the total phosphorus content was enhanced by NF 4, NF 1 and Normal micronutrients spray than other nanofertilizers, but significant effect was aroused only in 2015-16.

Total potassium content was significantly increased by foliar nutrition of NF 3 and NF 4 nanofertilizers in both years (2014-15 \& 2015-16). When compared to control, total potassium content was distinctively improved by commercially available nanofertilizers followed by micronutrient foliar spray.

The result revealed that foliar application of micronutrients ( $\mathrm{Zn}, \mathrm{Fe}, \mathrm{Cu} \mathrm{Mn}, \mathrm{B}$ and $\mathrm{Mo}$ ) is better way to deliver the needed nutrients in adequate concentration for enhancing the enzymatic activity, photosynthesis, respiration and protein synthesis which helps to improve the plant nutritional status as well as increase the yield (Smolen 2012). Yaseen et al., (2013) found the increased nutrient concentration of macro ( $\mathrm{N}, \mathrm{P}$ and $\mathrm{K})$ and micronutrients $(\mathrm{Zn}$, $\mathrm{Fe}, \mathrm{Cu} \mathrm{Mn}$ and $\mathrm{B}$ content) due to foliar application of higher dose of micronutrients $\left(3750 \mathrm{ml} \mathrm{ha}^{-1}\right)$ along with NPK. 
Table.1 Effect of foliar application of nanofertilizers on yield attribute and yield of cotton

\begin{tabular}{|c|c|c|c|c|c|c|c|c|c|c|c|c|}
\hline & \multicolumn{3}{|c|}{$\begin{array}{l}\text { No. of Symbodial } \\
\text { branches/plant }\end{array}$} & \multicolumn{3}{|c|}{ No. of opened bolls/plant } & \multicolumn{3}{|c|}{ Seed cotton yield (kg/ha) } & \multicolumn{3}{|c|}{$\begin{array}{l}\text { Total (shoot + root) dry } \\
\text { weight (g/plant) }\end{array}$} \\
\hline & 2014-15 & 2015-16 & Avg. & 2014-15 & 2015-16 & Avg. & 2014-15 & 2015-16 & Avg. & 2014-15 & 2015-16 & Avg. \\
\hline Control & 24.7 & 18.5 & 21.6 & 13.6 & 15.7 & 14.7 & 1257 & 1107 & 1182 & 159.5 & 144.5 & 152.0 \\
\hline $\begin{array}{l}\text { Micro } \\
\text { nutrients }\end{array}$ & 25.7 & 18.4 & 22.0 & 14.3 & 16.8 & 15.6 & 1277 & 1082 & 1180 & 124.8 & 135.8 & 130.3 \\
\hline NF 1 & 24.6 & 19.1 & 21.8 & 13.4 & 16.0 & 14.7 & 1327 & 1250 & 1289 & 142.4 & 151.4 & 146.9 \\
\hline NF 2 & 24.5 & 20.1 & 22.3 & 15.8 & 17.3 & 16.5 & 1383 & 1202 & 1292 & 145.7 & 169.8 & 157.7 \\
\hline NF 3 & 26.1 & 19.3 & 22.7 & 16.7 & 16.9 & 16.8 & 1403 & 1336 & 1369 & 199.8 & 149.1 & 174.4 \\
\hline NF 4 & 25.0 & 19.2 & 22.1 & 15.8 & 18.0 & 16.9 & 1407 & 1293 & 1350 & 271.9 & 145.7 & 208.8 \\
\hline S.Ed & 0.99 & 0.795 & & 1.11 & 0.858 & & 46.3 & 75.5 & & 26.9 & 23.1 & \\
\hline CD (0.05) & NS & NS & & NS & NS & & $103.2^{*}$ & $160.9^{*}$ & & $60.1^{* * *}$ & NS & \\
\hline
\end{tabular}

Table.2 Effect of foliar application of nanofertilizers on fibre quality parameters of cotton

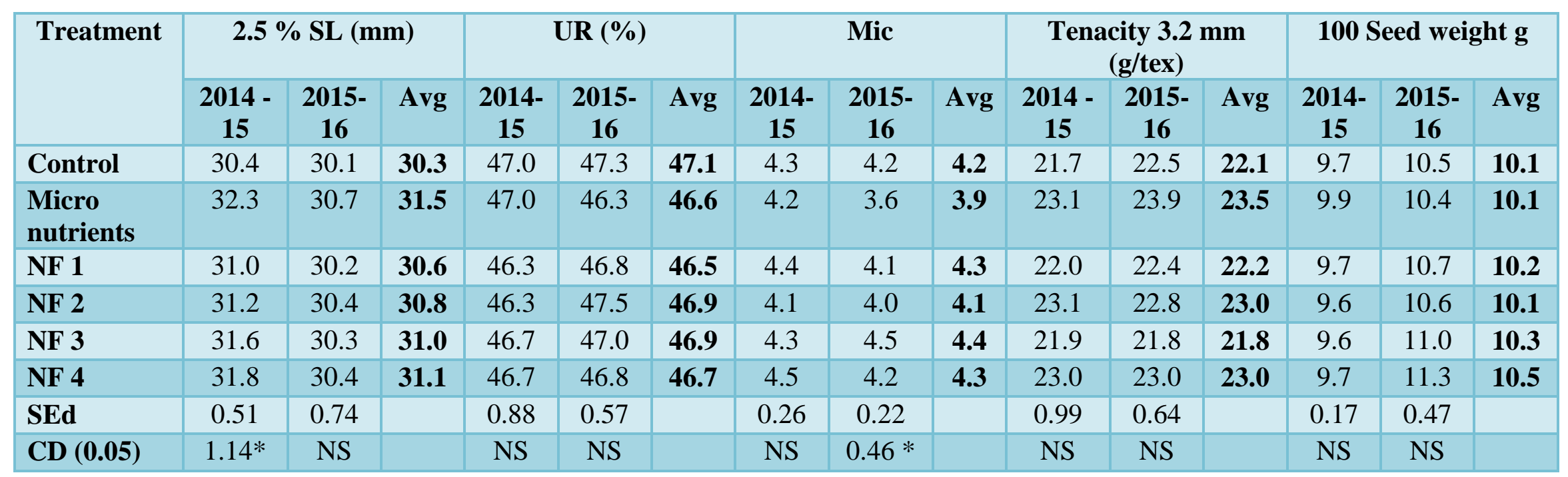

FQI - Fibre Quality Index; CSP - Count Strength Product 
Table.3 Effect of foliar application of nanofertilizers on macronutrient content in whole plants of cotton at harvest stage

\begin{tabular}{|c|c|c|c|c|c|c|c|c|c|}
\hline \multirow[t]{2}{*}{ Treatment } & \multicolumn{3}{|c|}{ Total N (\%) } & \multicolumn{3}{|c|}{ Total P (\%) } & \multicolumn{3}{|c|}{ Total K (\%) } \\
\hline & 2014-15 & 2015-16 & Avg. & 2014-15 & 2015-16 & Avg. & 2014-15 & 2015-16 & Avg. \\
\hline Control & 1.31 & 1.39 & 1.35 & 0.204 & 0.322 & 0.263 & 1.56 & 2.22 & 1.89 \\
\hline Micronutrients & 1.33 & 1.53 & 1.43 & 0.221 & 0.393 & 0.307 & 1.76 & 2.84 & 2.30 \\
\hline NF 1 & 1.27 & 1.55 & 1.41 & 0.226 & 0.356 & 0.291 & 1.78 & 2.84 & 2.31 \\
\hline NF 2 & 1.40 & 1.46 & 1.43 & 0.200 & 0.337 & 0.268 & 2.18 & 2.46 & 2.32 \\
\hline NF 3 & 1.32 & 1.82 & 1.57 & 0.206 & 0.345 & 0.275 & 2.10 & 2.79 & 2.44 \\
\hline NF 4 & 1.36 & 2.07 & 1.71 & 0.213 & 0.408 & 0.310 & 2.12 & 3.23 & 2.68 \\
\hline CD (0.05) & NS & 0.444 & & NS & $0.053^{*}$ & & $0.34^{* *}$ & $0.51^{*}$ & \\
\hline
\end{tabular}

Table.4 Effect of foliar application of nanofertilizers on micronutrient content (ppm) in whole plants of cotton at harvest stage (2014-15)

\begin{tabular}{|l|c|c|c|c|}
\hline & Zn (ppm) & Fe (ppm) & Cu (ppm) & Mn (ppm) \\
\hline Control & 105.6 & 793.4 & 7.8 & 55.4 \\
\hline Micronutrients & 121.2 & 914.1 & 7.8 & 57.3 \\
\hline NF 1 & 110.8 & 920.5 & 7.9 & 67.1 \\
\hline NF 2 & 160.0 & 963.4 & 11.9 & 71.7 \\
\hline NF 3 & 256.5 & 992.4 & 11.3 & 64.9 \\
\hline NF 4 & 130.4 & 929.4 & 9.3 & 73.6 \\
\hline CD $(\mathbf{0 . 0 5})$ & NS & NS & $1.65^{* *}$ & NS \\
\hline
\end{tabular}

Table.5 Economic analysis of seed cotton yield (average of two years) as influenced by foliar application of nanofertilizers

\begin{tabular}{|l|c|c|c|}
\hline Treatments & Additional Return (Rs/ha) & Net Return (Rs/ha) & Marginal Benefit: cost ratio (MBCR) \\
\hline NF 1 & 5500 & 2047 & $1.6: 1$ \\
\hline NF 2 & 5500 & 3812 & $3.3: 1$ \\
\hline NF 3 & 9500 & 7100 & $4.0: 1$ \\
\hline NF 4 & 8500 & 6381 & $4.0: 1$ \\
\hline
\end{tabular}

Dosage/ ha : NF 1 - 1563 g/ha, NF 2 - $125 \mathrm{ml} / \mathrm{ha}$, NF 3 - $1250 \mathrm{ml} / \mathrm{ha}$, NF 4 - $470 \mathrm{~g} / \mathrm{ha}$

Cost Rs/ha : NF 1 - 1953, NF 2 - 188, NF 3 - 900, NF 4-619; Seed cotton @ Rs. 5000/ha 


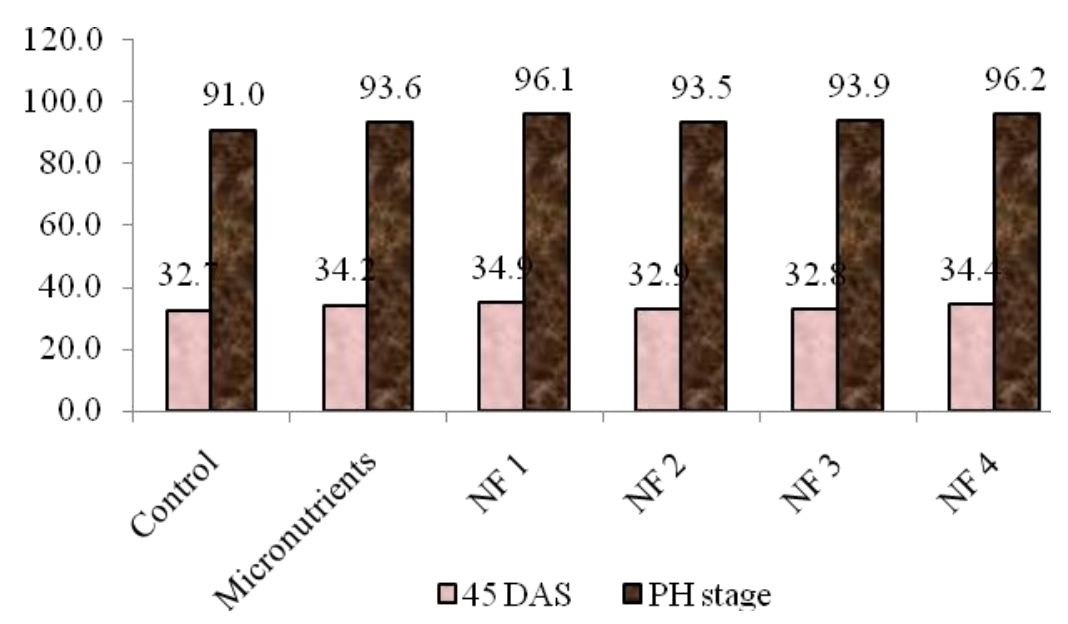

Fig.1 Effect of foliar application of nanofertilizers on plant height $(\mathrm{cm})$ of cotton (average of two years)

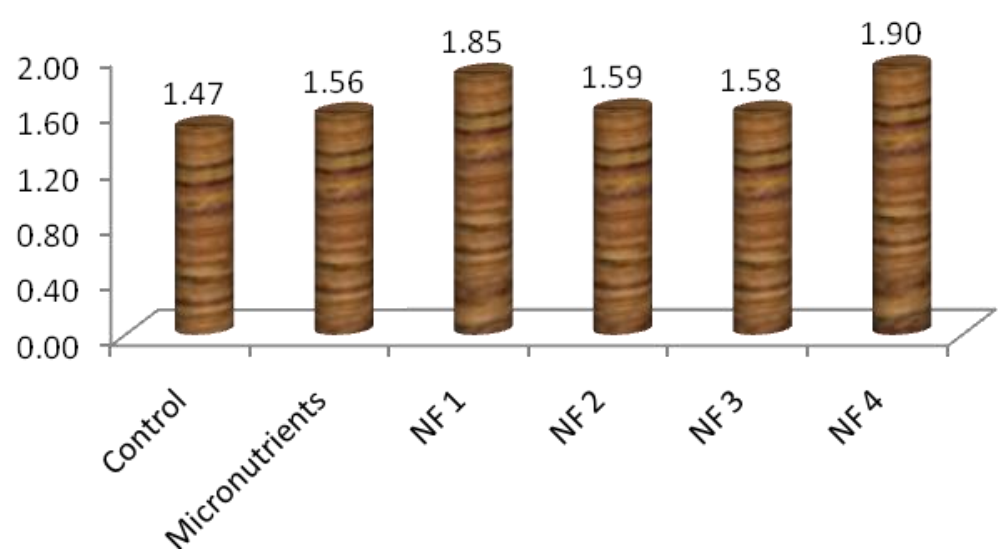

a. Leaf Area Index at harvest stage

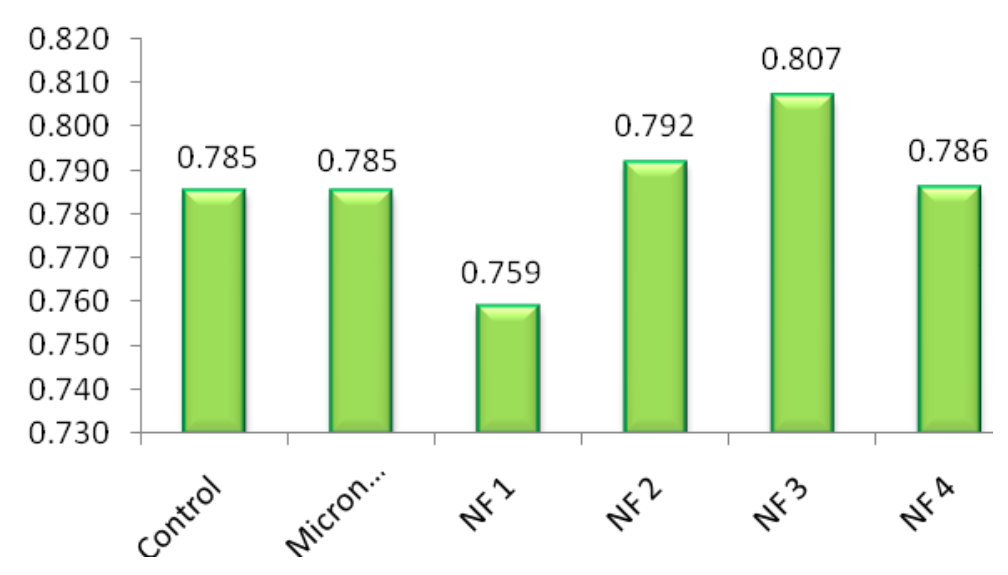

b. Total chlorophyll (mg/g) at 45 DAS

Fig.2 Effect of foliar application of nanofertilizers on physiological parameters of cotton (average of two years) 


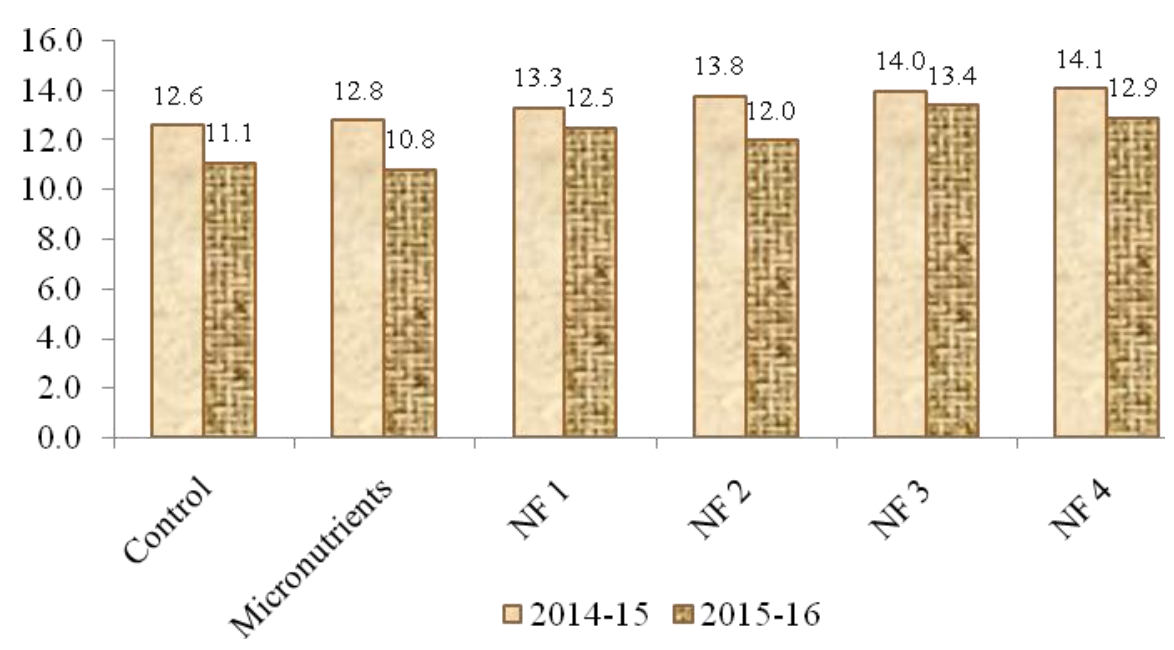

Fig.3 Effect of foliar application of nanofertilizers on seed cotton yield (q/ha) during two consecutive years (2014-15 and 2015-16)

In recent times, nanofertilizers are popular and very effective than conventional fertilizers to enhance the efficiency of nutrients use and improve the nutrient content of plants due to its unique characteristics of nanoparticles like smaller size, ability to engineer electron exchange, larger surface area and high surface reactive capabilities (Hatami et al., 2016). Specifically, the performance of nanoform of chelated micronutrients is excellent to increase the total nitrogen, total phosphorus and total potassium content which favoured for the highest seed cotton yield as compared to sulphate form fertilizers. This result was in line with the findings of Ebaid and El-Refaee (2007), who opined that chelated micronutrients fertilizer enhanced the nutrient availability for production and translocation of carbohydrates from source to sink which in turn yield was increased.

Foliar application of macro and micronutrient containing nanofertilizers notably increased all the cationic micronutrients viz., zinc, iron, copper and manganese as compared to normal micronutrient spray and control. Significant effect was registered only on increasing the copper content. Among the nanofertilizers, NF 3 nanofertilizer enhanced all the micronutrients like zinc (256.5 ppm), iron (992.4 ppm) and copper (11.3 ppm) content. This was followed by NF 2 and NF 4 nanofertilizers, where manganese content was higher (73.6 and 71.7 ppm respectively).

\section{Yield economics of cotton}

An economic analysis (Table 6) showed that foliar application of commercially available nanofertilizers like NF 3 and NF 4 produced the highest net return of Rs. 7100/- and Rs. 6381/- respectively with marginal benefit cost ratio (MBCR) of 4.0 followed by application of NF 2 (Rs. 3812 per ha) and NF 1 (Rs. 2047 per ha) nanofertilizers with MBCR of 3.3 and 1.6 respectively.

It is obviously cleared that application of NF 3 and NF 4 nanofertilizers performance was better on increasing the seed cotton yield, gross return, net return and MBCR than other two nanofertilizers like NF 2 and NF 1 nanofertilizers. Besides, it proved that these nanofertilizers are economical and cost effective on enhancing the cotton farmer's income. Economic benefit computed ranged from Rs.2.75 to 3.10 for every rupee invested on foliar nutrition practices on $\mathrm{Bt}$ cotton (Saravanan, 2009). 
As compared to conventional fertilizers, commercially available nanofertilizers viz., NF1, NF2, NF3 and NF4 were found to be better in increasing the growth and yield parameters, seed cotton yield and net return of cotton through foliar application. Among the four commercially available nanofertilizers, NF 3 and NF 4 nanofertilizers were highly desirable for increasing the seed cotton yield, improving the fibre quality characters and enhancing the nutrient concentration in cotton plants.

Moreover, the above two nanofertilizers also confirmed their cost effectiveness by increasing the marginal benefit cost ratio (MBCR), which showed the positivity on cotton farmer's income. Hence, this investigation endorsed that nanofertilizers are excellent alternate for traditional fertilizer and having potential to open up the new opportunity for fertilizer industry by excelling their performance on other crops.

\section{References}

Abdallah, A.M., and Mohamed H.F.Y. 2013. Effect of foliar application of some micronutrients and growth regulators on some Egyptian cotton cultivars. Journal of Applied Sciences Research. 9 (6): 3497-3507.

Abdul Qados, A. M. S., and Moftah, A. E. 2015. Influence of silicon and nanosilicon on germination, growth and yield of faba bean (Viciafaba L.) under salt stress conditions. American Journal of Experimental Agriculture. 5 (6): 509524.

Ajmal, F., Akram, M., Iqbal, R.M., Hussain,M., Hassan, M.W., Abdullah,M. and Wasaya, A. 2018. Effect of Exogenous Application of Micronutrients on growth and productivity of Cotton (Gossypium Hirsutum L.) crop. Bioscience Journal
Uberlandia. 34 (2): 302-311.

Bukovac, M.J. and Wittwer, S.H. 1957. Absorption and Mobility of foliar applied nutrients. Plant physiology. 32(5): 428-35.

Burström, H.G., Uhrström, I. and Wurscher, R. 2006. Growth, Turgor, Water Potential, and Young's Modulus in Pea Internodes. Physiologia Plantarum. 20(1):213 - 231 .

Cotton Advisory Board. 2019. In : Cotton sector, Ministry textiles. ministryoftextiles.gov.in

Datir, R.B.. Laware, S. L and Apparao, B. J. 2010. Effect of Organically Chelated Micronutrients on Growth and Productivity in Okra. Asian Journal of Experimental Biological Science. 115117.

Datir, R.B., Apparao B. J. and Laware S.L. 2012. Application of amino acid chelated micronutrients for enhancing growth and productivity in chili (Capsicum annum L.). Plant Sciences Feed. 2 (7): 100-105

Dordas, C. 2009. Foliar application of manganese increases seed yield and improves seed quality of cotton grown on calcareous soil. Journal of Plant Nutrition. 32: 160-176.

Ebaid, R.A. and El-Refaee, I.S. 2007. Utilization of rice husk as an organic fertilizer to improve productivity and water use efficiency in rice fields. African Crop Science Conference Proceedings. 8 : 1923-1928.

Etienne, P., Diquelou, S, Prudent, M, Salon, C, Maillard, A and Ourry A. 2018. Review on Macro and Micronutrient Storage in Plants and Their Remobilization When Facing Scarcity: The Case of Drought. Agriculture. 8: 14 Flores, R.A., Arruda, E.M., Damin, V., Junior, J.P.S., Maranhão, D.D.C., Correia, M.A.R., Prado, R.D.M. 2018. Physiological quality and dry mass 
production of Sorghum bicolor following silicon $(\mathrm{Si})$ foliar application. Australian Journal of Crop Science. 12 (04) :631-638.

Gerbrandt, E.M., Mouritzen,C. and Sweenev, M. 2019. Foliar Calcium Corrects a Deficiency Causing Green Fruit Drop in 'Draper' Highbush Blueberry (Vaccinium corymbosum L.). Agriculture, 9(3): 63.

Gobi, R. and Vaiyapuri, V. 2012. Effect of Sulphur, Zinc and Boron Fertilization on Growth, Yield,Quality and Economics of Irrigated Cotton (Gossypium hirsutum L.). International Journal of Agricultural Science. 3(3): 279-282.

Hatami, M., Kariman, K. and Ghorbanpour, M. 2016. Engineered nanomaterialmediated changes in the metabolism of terrestrial plants. Science of the Total Environment. 571: 275-291.

Hirschi, K.D. 2004. The Calcium Conundrum. Both Versatile Nutrient and Specific Signal. Plant Physiology, American Society of Plant Biologists. 136: 2438-2442.

Janmohammadi, M., Amanzadeh, T., Sabaghnia, N. and Ion, V. 2016. Effect of nano-silicon foliar application on safflower growth under organic and inorganic fertilizer regimes. Bot Lithuan. 22(1):53-64

Jie, M., Raza, W., Xu, Y.C. and Shen, Q. 2008. Preparation and Optimization of AminoAcid Chelated Micronutrient Fertilizer by Hydrolyzation of Chicken Waste Feathers and the Effects on Growth of Rice. Journal of Plant Nutrition. 31: 571-582.

Kanjana D. 2017. Advancement of Nanotechnology Applications on Plant Nutrients Management and Soil Improvement, In: Nanotechnology: Food and Environmental Paradigm", Springer Nature Singapore Pvt. Ltd, R.
Prasad et al., (Eds). 2017, 209-234.

Norman, S. and Hongda, C. 2013. IB IN DEPTH Special Section on Nanobiotechnology, Part 2. Ind. Biotechnol, 9 :17-18.

Padma, M., Reddy, S. A. and Babu, R. 1989. Effect of foliar sprays of molybdenum (Mo) and boron (B) on vegetative growth and dry matter production of French bean (phaseolus vulgaris L.). Journal of Research Andhra Pradesh Agriculture University. 17: 87-89.

Perez-de-Luque, A. 2017. Interaction of Nanomaterials with Plants: What Do We Need for Real Applications in Agriculture? Front. Environ. Sci.5: 12.

Rajput, L.B., Gilal, A.A., Abro, G.H., Mastoi, M.I., Sahito, J.G.M. and Nizamani, I.A. 2016. Effect of application of micronutrients on the lint quality Parameters of cotton. Science International (Lahore). 28(2):12951298.

Sahebi, M., Hanafi, M.M., Akmar,A.S.N., Rafii, M.Y., Azizi, P., Tengoua, F. F., Azwa, J.N.M. and Shabanimofrad, M. 2015. Importance of Silicon and Mechanisms of Biosilica Formation in Plants. Biomedical Research International. p. 1- 16.

Sankaranarayanan, K, Praharaj, C.S., Nalayini, P., Bandyopadhyay, K.K. and Gopalakrishnan, N. 2010. Effect of magnesium, zinc, iron and boron application on yield and quality of cotton (Gossypium hirsutum). Indian Journal of Agricultural Science. 80: 699-703.

Saravanan, M. 2009. 'Effect of foliar nutrition on Bt cotton-Bunny'. M Sc thesis, Tamil Nadu Agricultural University, Coimbatore.

Sekhon, B.S. 2003. Chelates for Micronutrient Nutrition among Crops. Resonance, July, 2003

Shahrekizad, M., Ahangar, A.G. and Mir, N. 
2015. EDTA-Coated $\mathrm{Fe} 3 \mathrm{O} 4$ Nanoparticles: a Novel Biocompatible Fertilizer for Improving Agronomic Traits of Sunflower (Helianthus Annuus). Journal of Nanostructures. 5 :117-127.

Smoleń, S. 2012. Foliar Nutrition: Current State of Knowledge and Opportunities. In: A. K. Srivastava (Ed.), Advances in Citrus Nutrition, Springer Science + Business Media, pp. $41-58$.

Solanki, P., Bhargava, A., Chhipa, H., Jain, N. and Panwar, J. 2015. Nano-fertilizers and Their Smart Delivery System. In: Nanotechnologies in Food and Agriculture. Springer International Publishing Switzerland. M. Rai et al., (Eds.), P. 81-102.

Tahir, M., Fiaz, N., Nadeem, M.A., Khalid, F. and Ali, M. 2009. Effect of different chelated Zinc sources on growth and yield of maize. Soil and Environment. 28:179-183.

Tariq, A., Anjum, S.A., Randhawa, M.A., Ullah, E., Naeem, M., Qamar, R., Ashraf, U. and Nadeem, M. 2014. Influence of Zinc Nutrition on Growth and Yield Behaviour of Maize (Zea mays L.) Hybrids. American Journal of Plant Sciences. 5: 2646-2654

Temiz, M., Koca, Y.K., Aydin, F. and Karahan, E. 2009. Effect of foliar potassium and micronutrient additions on yield and fiber quality of cotton (Gossypium hirsutum L.). Journal of Food, Agriculture \& Environment. 7 (1): 118-122.

Wanyika, H., Gatebe, E., Kioni, P., Tang, Z. and Gao, Y. 2012. Mesoporous silica nanoparticles carrier for urea: potential applications in agrochemical delivery systems. Journal of Nanoscience and Nanotechnology. 12(3): 2221-2228.

Yassen, A., Abdallah, E., Gaballah, M. and Zaghloul, S. 2017. Role of Silicon Dioxide Nano Fertilizer in Mitigating Salt Stress on Growth, Yield and Chemical Composition of Cucumber. International Journal of Agricultural Research. 12: 130-135.

Yaseen, M., Shahbaz,M. and Shahbaz, M. 2013. Role of foliar feeding of micronutrients in yield maximization of cotton in Punjab. Turkish Journal of Agriculture and Forestry. 37(4): 420426.

\section{How to cite this article:}

Kanjana. D. 2020. Evaluation of Foliar Application of Different Types of Nanofertilizers on Growth, Yield and Quality Parameters and Nutrient Concentration of Cotton under Irrigated Condition. Int.J.Curr.Microbiol.App.Sci. 9(07): 429-441. doi: https://doi.org/10.20546/ijcmas.2020.907.048 